\title{
Internet Use and its Contributions to the Social Development of University Business Education Undergraduates in Anambra State Nigeria
}

\author{
Ezenwafor Justina I Ph. D, Ukwuoma Annette Amaka \\ Department of Technology and Vocational Education, \\ Nnamdi Azikiwe University, Awka, Nigeria
}

\begin{abstract}
The Internet has become an essential component of students' everyday life throughout the world. It has revolutionalized the way students communicate, interact and socialize. Use of the Internet can have positive or negative influence on students' overall development. The need to ensure effective use of the Internet by university students necessitated this study to determine its contributions to the social
\end{abstract} development of university business education undergraduates in Anambra State. One research question guided the study and two null hypotheses were tested at 0.05 level of significance. Survey research design was used. Population was 647 university business education undergraduates in Anambra State of the 2015/2016 academic session. Purposive sampling technique was used to draw a sample size of 156 (63 male and 93 female students) for the study. Instrument for data collection was a 5point rating scale questionnaire which was duly validated by three experts. The internal consistency of the instrument was determined using Cronbach Alpha. Data were analyzed using the arithmetic mean and standard deviation to answer the research question and determine the closeness of respondents' means while z-test and ANOVA were used to test the null hypotheses at 0.05 level of significance. Findings revealed that the respondents strongly agreed that the Internet contributes to their social development. It was also found that Gender and institution ownership did not significantly affect the respondents' mean ratings on the contributions of the Internet to their social development. Based on the findings, it was concluded that the Internet is a very helpful tool that facilitates students' social development. It was recommended among others that parents should monitor their children to see what they do with their time while

business educators should organize seminars in schools to enlighten students on how to effectively utilize the Internet for their social and overall development.

Keyword: Contributions, Internet, Social Development, Business Education

\section{INTRODUCTION}

\section{Background to the Study}

Education is at the heart of every society as an instrument per excellence in effecting social, intellectual and developmental transformations of a people. It is in recognition of this fact that governments commit immense resources to ensure the provide education for their citizens and also tailor their policies towards ensuring that it is accessible to the generality of their citizenry. The 1990 Longe Commission reviewed Higher Education in Nigeria and noted that education is the most powerful instrument for social reform. Business education is an essential element of this general education which is required by all citizens regardless of field of interest. According to Isu in Ubulom and Dambo (2016), business education is that type of education that deals with the acquisition of knowledge, practical skills and values that enable an individual to function effectively in the society. University business education programme aims at producing responsible, productive and self-reliant citizens.

A university is an institution of higher education and research which awards academic degrees in different field at undergraduates and postgraduate levels (Aronowitz, 2000). Most university students in Nigeria including those studying business education 
are believed to be utilizing Internet in pursuit of academic, social, economic and intellectual goals, while some seem not to be availing themselves of the vast benefits. According to Ogedebe (2012), Internet is a large computer network formed out of thousands interconnected networks which supports a whole range of services like electronic file transfer protocol, database access and many others. Internet is a network of networks that consists of millions of private, public, academic, business and government networks with local to global scope that are linked by a broad array of electronic, wireless and optical networking technologies (Anick, 2007). The Internet can transform undergraduate learning process to student -centred learning rather than lecturer or faculty - centred and can contribute immensely to proper development of university students.

Development is a state in which things are improving. It also mean a gradually change, progressing through a number of stages towards some sort of expansion, improvement or completeness or a state in which the subjects' true identity is revealed (Emeh, 2012). Students' development covers academic development, social development and economic development among others. This study is delimited to social development which focuses on promoting people's welfare or social well-being.

Gender and institution ownership are respondent variables that may affect Internet use and its contributions to social development of university business education undergraduates since there are some differences in opinions and activities between men and women as well as fundings status in universities based on ownership. For example, Sanni, Awoleye, Egbetokun, and Siyanbola, (2009) reported a gender difference in Internet use and therefore recommended that adequate attention should be paid to ensure equal access to the facility among male and female students. Therefore, the study determined the influence of gender and institution ownership in the respondents' ratings on the contributions of the Internet to the social development of university business education undergraduates in Anambra State.

\section{Statement of the Problem}

The growing dimensions of Internet use among university undergraduates today significantly affect their social interaction by changing the way they interact face-to-face and receive information as well as the dynamics of their social groups and friendships.
The high level of usage of the Internet via social networking sites in universities has raised dust among different stakeholders education. Some see it as distraction to learning for the students as it involves multitasking, while others attest to its potentials for enhancing students' social development. The researchers are worried that despite the emergence of the Internet and numerous social networking sites (SNSs) like Facebook, Whatsapp,2go,Twitter among others which can enhance students' social and overall development, university business education undergraduates seem not to be harnessing these enormous potentials. Many of these students are constantly busy with their laptops and mobile phones taking pictures, chatting and updating profiles even when lectures are on in the classroom. This study is therefore deemed imperative as it will influence a better use of the Internet for social and overall development of university business education undergraduates in Anambra State.

\section{Purpose of the Study}

The purpose of the study was to determine the contributions of the Internet to the social development of university business education undergraduates in Anambra State.

\section{Research Questions}

One research question guided the study; thus

1. How does the Internet contribute to the social development of university business education undergraduates in Anambra State?

\section{Hypotheses}

The following null hypotheses were tested at 0.05 level of significance.

1. Male and female university business education undergraduates in Anambra State do not differ significantly in their mean ratings on the contributions of the Internet to their social development.

2. Business education undergraduates in federal, state and private universities in Anambra State do not differ significantly in their mean ratings on the contributions of the Internet to their social development.

\section{Literature Review}

Related literatures to this study were reviewed as follows: 


\section{Contribution}

Contribution is a part played by a person or thing in bringing about a result or helping something to advance (Hornby, Turnbull \&Wehmeler, 2010). The authors explained that contribution is the role played in achieving something, the part played by somebody or something in causing a result. A contribution can take many forms. Some contributions are measurable, like donation, others are less tangible. When a student raises his hand in class to ask a question, he is making a contribution, because the answer to his question enriches the other students' learning experience. Nevertheless, since a contribution is always a result oriented mechanism, it often poses a challenge to the system requiring its input.

\section{Internet}

The Internet is the newest and fastest growing part of the age of information technology. The inception of the Internet actually began over 60 years ago as a United States Defense Department Project. The Internet is now a global computer network that allows millions of computers around the world to communicate through the telephone system and other communication lines. In this study, Internet can be defined technically and functionally, as a worldwide network of computers and a network of people using computers that make vast amounts of information available. The advent of social network media and social network sites such as Facebook, Twitter, Linkedin and others that include chatting and online games have changed the perception on Internet use from one that is associated with learning to that of a socializing facility. The concept of social media was shared by Lusk (2010) as the use of Facebook, Blogs, Twitter, My Space and LinkedIn for the purpose of communication, sharing photos as well as videos. However, for the purpose of this study social media is captured within the use of Internet through social networking sites (SNSs) such as Facebook, Whatsap, Twitter, Skype, MySpace as well as Yahoo Messenger for communication, sharing of ideas, sharing of photos and videos by users.

Some social networking sites commonly used by students include:

1. Facebook: With Facebook, you can browse and join networks, pull contacts from a web-based email account, find friends in several ways, upload pictures and video clips and so on. Facebook has recently crossed millions of users and is the most popular social networking site of the world.
2. MySpace: MySpace is an online community that lets people to meet their friends' friends, share photos, journals and interest. When you join MySpace, the first step is to create a profile. You then, invite friends to join there and search for your friends already profiled on MySpace (Cecconi in Eserinune, 2015).

3. Wikiis a group of Web pages that allows users to add content, similar to a discussion forum or blog, but also permits others (sometimes completely unrestrictedly) to edit the content.

4. Twitter: According to Reuben in Eserinume (2015), twitter is a social networking and micro blogging service, utilizing instant messaging, signs or a web interface enabling its users to send and read messages. Twitter service can be used to post and receive messages to a network of contacts, as opposed to send bulk email messages.

5. LinkedIn: LinkedIn is an online social network for business professionals, which is designed specifically for professional networking, to help them find a job, discover sales leads, connect with potential business partners.

6. Blogs: Are a form of online journal. They can have a single author, or several. Most blogs allow readers to post comment in response to articles or posts. Blogs are being used by some colleges and universities to post news articles to open conversations about them.

7. YouTube: YouTube is a popular video sharing website where users can upload, view, and share video clips. YouTube has become an enormously popular form of web 2.0 new media. Other social networks include; Bebo, Friendster, Ning, Classmates, Tagged, My Year Book (Eserinune, 2015).

\section{Benefits of Using Internet Services}

There is evidence of a broad range of benefits to undergraduates associated with the use of social networking services. The researcher summarizes these as strengthening social relationships, creativity, individual identity and self-expression, sense of belonging and collective identity and developing new interpersonal relationships. Beasley (2008) reported that Internet use has been found to strengthen university undergraduates existing interpersonal relationships. Internet use helps students to be creative. University undergraduates are more immersed in this participatory media environment than any other age-group. According to Valtysson (2010), Internet via social networking services is 
increasingly important for individual identity and selfexpression. University undergraduates' use of Internet is important for strengthening and developing social relationships, particularly as the online and offline worlds converge. Internet through social networking service plays a significant role in the formation of new forms of collective identity facilitating a sense of connectedness, community and belonging.

\section{Social Development}

The definition of development has been a major area of controversy. Implicit value assumptions and associated policy responses are logically linked to the nature of the definitions employed. Development means a progression from a simpler or lower to a more advanced, mature, or complex form or stage. It is also defined as the gradual advancement or growth through a series of progressive change. According to Azikiwe in Nwazor (2012), development simply implies a change in a forward direction; a modification in the positive sense; and a change of an improvement. Development in its simplest definition and perhaps in its common usage can be considered as the objective of moving to a state relatively better than what previously existed. Social development may be viewed as an approach for promoting people's welfare or social well-being. Social development is defined in the broadest social terms as an upward directional movement of society from lesser to greater levels of energy, efficiency, quality, productivity, complexity, comprehension, creativity, choice, mastery, enjoyment and accomplishment. The objectives of social development can be summarized as ensuring poverty eradication, full employment, and social integration.

\section{University Business Education}

Although the concept "business education" is frequently used, it is still in semantic flux. A generally acceptable definition has been difficult to arrive at because there are as many different meanings of the concept as there are many experts who have tried to define it. Business education includes education for an office occupations, distribution and marketing occupations, accounting, business teaching, business administration and economic understanding. Business education covers a wide range of spectrum of economic life activities in any society and also refers to the pedagogical and desirable business competencies necessary for self-employment or being employed with a view to making the recipient selfreliant (Amesi, 2010). The researcher observed that the objectives of business education programmecentre on preparing the beneficiaries to function effectively in the industry as employees, in the classroom as professional teachers and in the business world as entrepreneurs. Aliyu in Ezenwafor and Ementa (2016) outlined the objectives of business education at the tertiary level to include:

1. Providing a matured understanding of the general nature of business

2. Providing the needed background for teaching in business subjects.

3. Providing training for leadership in business.

4. Providing training in specialized phases of business activity.

5. Laying a cultural and ethical foundation for the development of the foregoing objectives.

The major aim of business education programme at this level of education is to empower its recipient for effective work performance on graduation.

\section{Internet Usage and Social Development}

Oladipo and Mamman (2014) investigated students' perceptions regarding the impact of social media on business education in Nigeria Universities. The study found among others that, students use social media platform for personal/entertainment purposes with Facebook and e-mail emerging as the favorites, therefore it was concluded that social media have positive impact on business education students. Similarly, Sponcil and Gitimu (2014) conducted a study on social media use among college students and how it affects their communication with others and their self-concept. It was found that almost all college students were using some form of social networking website for communication with family and friends, entertainment releasing boredom and influencing individual's self-concept. Omekwu, Eke and Odoh (2014) studied the use of social networking sites among undergraduate students of the University of Nigeria, Nsukka. The study revealed that mostly all the students were using the social networking sites in interacting with friends, connecting their class mates for online study and for discussing serious national issues as well as watching movies. In another study on the effects of social networks by college students, Mohamed, Fouad, Ismail and Mohammad (2014) reported that a significant number of students enjoy having online discussions with their colleagues and believe that online study groups can improve their study and communicative skills. 


\section{Method}

Descriptive survey research design was adopted for the study. According to Abimbola (2014), descriptive survey design is concerned with collecting data from members of a population in order to determine conditions that exist, opinions that are held and processes that are going on. The study was carried out in Anambra State of Nigeria. The choice of the area for the study was informed by the fact that three out of the four universities in the area offer business education at the undergraduate level with most of the students having Internet enabled devices. The population of the study comprised 647 (263 males and 384 females) business education undergraduates from the three universities for the 2015/2016 academic session. Purposive sampling technique was used to select 156 (63 males and 93 females) 400 level students from the population based on the fact that their length of stay in the programme had sufficiently exposed them to the contributions and challenges of the Internet to their development. Data for the study were collected with five-point rating scale questionnaire which was validated by three experts, two from the Department of Technology and Vocational Education and one from the Department of Education Foundation in the Faculty of Education, Nnamdi Azikiwe University, Awka. The reliability of the instrument was determined through trial-testing using 20 business education students from the University of Nigeria Nsukka who were not part of the study population. Data obtained were analyzed with Cronbach Alpha to obtain a reliability coefficient of 0.82 . The instrument was administered to the respondents in their schools personally by the researchers with the help of one final year lecturer in each school. This yielded a high response rate as 144 copies (representing 92.31 percent) of were retrieved and used for the study. The arithmetic mean was used to answer the research question while the standard deviation was used to determine the closeness of the respondents' mean ratings. The inferential statistics of z-test was used to test the null hypothesis 1 and Analysis of Variance (ANOVA) was used to test the null hypothesis 2 at 0.05 level of significance.

\section{Results}

\section{Table 1: Respondents' Mean Ratings on the Contributions of Internet to the Social Development of} University Business Education Undergraduates

\begin{tabular}{|c|c|c|c|c|}
\hline S/N & Items & Mean & SD & Remarks \\
\hline 1. & The Internet helps me to make new friends & 4.63 & 0.66 & $\begin{array}{c}\text { Strongly } \\
\text { Agree }\end{array}$ \\
\hline 2. & Social networks often add to my communicative abilities & 4.60 & 0.63 & $\begin{array}{c}\text { Strongly } \\
\text { Agree }\end{array}$ \\
\hline 3. & $\begin{array}{c}\text { It is easy for me to learn more social } \\
\text { facts from the Internet }\end{array}$ & 4.02 & 0.99 & Agreed \\
\hline 4. & $\begin{array}{c}\text { Internet helps me in the use of social networks for easy access to my } \\
\text { mails and message }\end{array}$ & 4.66 & 0.56 & $\begin{array}{c}\text { Strongly } \\
\text { Agree }\end{array}$ \\
\hline 5. & I easily get news from the Internet & 4.69 & 0.66 & $\begin{array}{c}\text { Strongly } \\
\text { Agree }\end{array}$ \\
\hline 6. & The Internet helps me to have easy access to my friends. & 4.80 & 0.88 & $\begin{array}{c}\text { Strongly } \\
\text { Agree }\end{array}$ \\
\hline 7. & $\begin{array}{c}\text { The use of Internet helps me to easily collaborate with classmates } \\
\text { on social need }\end{array}$ & 3.74 & 0.91 & Agree \\
\hline & Cluster Mean & $\mathbf{4 . 5 9}$ & & $\begin{array}{c}\text { Strongly } \\
\text { Agree }\end{array}$ \\
\hline
\end{tabular}

Table 1 shows that five out of the seven items have mean rating of 4.6 and above while the remaining two have mean ratings from 3.74 to 4.02 . The cluster mean of 4.59 shows that the respondents strongly agreed that the Internet contributes to the social development of university business education undergraduates in Anambra State. 
International Journal of Trend in Scientific Research and Development (IJTSRD) ISSN: 2456-6470

Table 2: Summary of $Z$ - test Analysis of Male and Female Respondents on the Contributions of the Internet to their Social Development

\begin{tabular}{|c|c|c|c|c|c|c|c|c|}
\hline Gender & $\mathbf{N}$ & Mean & SD & $\boldsymbol{a}$ & df & Z-cal & Z-crit & Remark \\
\hline Male & 53 & 4.30 & 1.01 & \multirow{2}{*}{0.05} & \multirow{2}{*}{142} & 0.179 & 1.96 & Not Significant \\
\cline { 1 - 6 } Female & 91 & 4.33 & 0.92 & & & & & \\
\hline
\end{tabular}

Table 2 shows that the calculated $\mathrm{z}$ value of 0.179 is less than the critical $\mathrm{z}$-value of 1.96 at 0.05 level of significance and 142 degree of freedom. This means that male and female business education undergraduates in Anambra State do not differ significantly in their mean ratings on the contributions of the Internet to their social development. Therefore, the null hypothesis was upheld.

Table 3: (ANOVA) Summary of the Mean Ratings of Business Education Undergraduates in Federal, State and Private Universities in Anambra State on the Contributions of the Internet to their Social Development

\begin{tabular}{|c|c|c|c|c|c|c|}
\hline Sources of Variance & Sum Squares & Df & Mean Square & F-cal & F-crit & Remark \\
\hline Between Groups & 0.1 & 2 & 0.05 & 0.35 & 3.56 & Not Significant \\
\hline Within Groups & 2.57 & 18 & 0.142 & & & \\
\hline Total & 2.67 & & & & & \\
\hline
\end{tabular}

Table 3 shows that the F-cal of 0.35 is less than the F-crit of 3.56 at 0.05 level of significance with 2 and 18 degree of freedom. This means that business education undergraduates in federal, state and private institutions do not differ significantly in their mean ratings on the contributions of the Internet to their social development. The null hypothesis was therefore upheld.

\section{Discussion}

The findings of this study revealed that business education undergraduates in the area of the study strongly agreed that the Internet contributes to their social development. The findings show that the Internet gives undergraduates easy access to old friends and enables them make new friends. These findings are in accordance with that of Sponcil and Gitimu (2014) which revealed that the most important reason given by students for using the Internet was to communicate with family and friends. The study also revealed that Internet enables students easily access to their mails and messages. This finding also agreed with Oladipo and Mamman (2014) report that students use social media platform for personal/entertainment purposes with Facebook and e-mail being the favorites.

Findings of the study also showed that gender and institution ownership did not significantly factors influence students' mean ratings on the responses on the contributions of the Internet to their social development. This finding is in contrast with Asabere (2012) and Enang (2014) who reported that male students utilize Facebook and other social networking sites more than their female counterparts.
The findings also showed that Internet helps undergraduates learn more communicative skills and gain easy access to their mails and messages. This finding is in line with the report of Mohamed, Fouad, Ismail and Mohammad (2014) which revealed that online study groups improves students' study and communicative skills.

\section{Recommendations}

Based on the findings of this study, it was recommended that:

1. University students should be re-oriented on the need to set their priorities right by exposing them to the positive and negative effects of overdependency and unregulated use of the Internet to their social development.

2. University lecturers should help educate their students on how to effectively utilize Internet for social purposes and the impact it will have on their communicative abilities and collaboration with friends and classmates on social need.

3. Parents should monitor their children Internet activities at home to ensure that they use it to communicate with their friends, help them to make new friends and gives them limitless access to the world. 
4. The Association of Business Educators of Nigeria (ABEN) should organize seminars and workshops in universities to enlighten students on how to effectively utilize the Internet for their social development.

\section{REFERENCES}

1. Abimbola, O. A. (2014). Challenges in using emerging technology in the teaching of office technology and management courses in tertiary institutions in the South West Nigeria. Nigerian Journal Business Education, 3, 46-63.

2. Amesi, J. (2010). Business education and poverty alleviation. Orient Journal of Education UnizikAwka, 5(1), 57 - 62.

3. Anick, J. (2007). Internet makeover? Some argue it's time. Retrieved $8^{\text {th }}$ October, 2015 from http://seattletimes.nwsource.com/html/businesstec hnology/2003667811btrebuildnet16.ml

4. Aronowitz, S. (2000). The knowledge factory: Dismantling the corporate university and creating true higher learning. Boston Press.

5. Asabere, N. Y. (2012). A research analysis of online social networking sites (SNSs) and social behaviour at university of Ghana (UG), Legon, Accra, Ghana. International Journal of Science and Technology, 2(3), 7-17.

6. Besley (2008). Cyber bullying: An emerging threat to the "always on" Generation in Canadian Teacher Magazine, 18-20.

7. Emeh, E. J. (2012). Tackling youth unemployment in Nigeria; The Lagos State development and empowerment programmes initiatives. Afro Asian Journal of Social Sciences, 3(3), 1-30.

8. Enang, C. E. (2014). The use of social media in collaborative professional development of business education teachers in Nigeria. Association of Business Educators of Nigeria, 1(2), 77-86.

9. Eserinune, M. M. (2015). Mobile phone usage among Nigerian university students and its impact on teaching and learning. Global Journal of Arts Humanities and Social Sciences, 3(1), 29-38.

10. Ezenwafor, J. I. \& Ementa, C. N. (2016). Assessment of constraining factors to e-learning adoption by business educators in tertiary institutions in Anambra State. International Journal of Innovative Education Research, 4(2), 22-31.
11. Hornby, A. S., Turnbull, J., \& Wehmeler, S. (2010). Oxford advanced learners dictionary $8^{\text {th }}$ edition. London: Oxford University Press.

12. Lusk, B. (2010). Digital natives and social media behaviors: An overview. The Prevention Research, 17, 3-6.

13. Mohammed, T., Fouad, Z., Ismail, A. \& Mohammad N. S. (2014).Social network: Academic and social impact on college students. ASEE 2014 Zone I Conference, April 3-5, University of Bridgeport, Bridgpeort, CT, USA.

14. Nwazor, J. C. (2012). Capacity building, entrepreneurship and sustainable development.

Journal of emerging trends in educational research and policy studies. (JETERAPS), 3(1), 51-54.

15. Ogedebe, P. M. (2012). Internet usage and students' academic performance in Nigeria tertiary institutions: A case Study of University of Maiduguri. Academic Research International, 2(3), 334-343.

16. Oladipo, A. T. \& Mamman, J. S. (2014). Students perceptions regarding the impact of social media on business education in Nigeria universities. Conference proceedings, 1(2), 87-93.

17. Omekwu, C. O., Eke, H. N. \& Odoh, J. N. (2014). The use of social networking sites among the undergraduate students of university of Nigeria, Nsukka. Retrieved from: http//www.google.com on 12/5/2016.

18. Sanni, M., Awoleye, O. M., Egbetokun, A. A. \& Siyanbola, W. O. (2009). Harnessing the potentials of Internet technology for research and development among undergraduates in Nigeria: A case study of Obafemi Awolowo University. International Journal of Computing and ICT Research, 3, $1-32$.

19. Sponcil, M. \& Gitimu, P. (2014). Use of social media by college students: Relationship to communication and self-concept. Journal of Technology Research, 1 - 13.

20. Ubulom, W. J. \& Dambo, B. I. (2016). An evaluation of the objectives of the undergraduate business education degree programmes in some Nigerian universities. International Journal of Innovative Education Research, 4 (1), 26-35.

21. Valtysson (2010). Access culture: Web 2.0 \& cultural participation. International Journal of Cultural Policy, 16(2), 200 - 214. 